\title{
Technical assessment of discarded tires gasification as alternative technology for electricity generation
}

\author{
Einara Blanco Machin*, Daniel Travieso Pedroso, João Andrade de Carvalho Júnior \\ UNESP - Universidade Estadual Paulista, Faculdade de Engenharia de Guaratinguetá, Av. Dr. Ariberto Pereira da Cunha 333, Portal das Colinas, Guaratinguetá, São Paulo, \\ 12516-410, Brazil
}

\section{A R T I C L E I N F O}

\section{Article history:}

Received 16 December 2016

Revised 29 April 2017

Accepted 4 July 2017

Available online 13 July 2017

\section{Keywords:}

Used tires

Cogeneration

Tire Derived Fuel

Bubbling Fluidized Bed

Gasification

\begin{abstract}
A B S T R A C T
Concern about contamination associated with the disposal of tires has led to the search for technologies to reuse discarded tires, which include the use of Tire Derived Fuel (TDF) as fuel in advanced thermalconversion processes, this allows the energy use of these wastes at affordable costs and reduces the environmental impact on scrap tires disposal. A theoretical assessment of the technical viability of TDF gasification for electric and thermal power generation, from the producer gas combustion in an internal combustion engine and in a gas turbine, was performed. The combustion of producer gas derived from the gasification of TDF in an internal combustion engine driving a generator (ICE-G) appears as the more efficient route for electricity generation when compared with the efficiency obtained with the use of gas turbine (GT-G). A higher global efficiency, considering the electric and thermal generation efficiency can be expected with the use of TDF producer gas in GT-G, where is expected an overall efficiency of $77.49 \%$. The assessment shows that is possible produces up to $7.67 \mathrm{MJ}$ and $10.62 \mathrm{MJ}$ of electric and thermal energy per kilogram of TDF gasified using an ICE-G and up to $6.06 \mathrm{MJ}$ and $13.03 \mathrm{MJ}$ of electric and thermal energy respectively per kilogram of gasified TDF using a GT-G.
\end{abstract}

(C) 2017 Elsevier Ltd. All rights reserved.

\section{Introduction}

Tire disposal is a problem throughout the world that is aggravated as the vehicle fleet grows. The tire must have proper disposal procedure, to reduce their impact on the environment. However, most of the time, incineration becomes the disposal procedure, since it is the fastest and easiest way to discard it. Tire incineration forms hundreds of different combustion products, ranging from simple to complex hydrocarbons and halogechlorinated hydrocarbons (ranging from chlorinated methanes to the ultra-toxic dioxins and polychlorinated biphenyl (PCBs)) (Lew, 1990). Pyrolytic oil, is also produced which contains toxic chemicals and heavy metal compounds, capable to cause adverse health effects.

The estimated number of waste tires generated annually in Brazil rounds between 17 and 20 million units, from which 6 million units are generated in the state of São Paulo. The number of accumulated units in inappropriate deposits is estimated to be at least 100 million units (Andrade, 2007; ABRELPE, 2015).

Concern about contamination associated with the disposal of tires has led to the search for technologies to reuse discarded tires, which include energetic valorization, introduction as raw material

\footnotetext{
* Corresponding author.

E-mail address: einara@feg.unesp.br (E.B. Machin).
}

in buildings construction, in the processing of asphalt surfacing and in the footwear industry, among others.

Due to its high calorific value, scrap tires are widely used as fuel in thermoelectric generation, in co-combustion coal-fired boilers and in the production of oils. Another major objective for uses of tires as fuel is to decrease the number of scrap tires disposed in landfills or stockpiles.

These applications however, are questioned due the pollutant emissions levels. According to United States Environmental Protection Agency (Marchiori, 2007), tire combustion emits approximately $6 \%$ of the burned fuel mass as solid particles and volatiles.

The use of Tire Derived Fuel (TDF) as fuel in advanced thermalconversion processes with low contaminants emissions is a promising alternative in the market today, which allows the energy use of these wastes at affordable costs and reduces the environmental impact on the scrap tires disposal. Some experimental and theoretical studies on waste tires gasification at laboratory scale has been performed, mainly using plasma and steam gasification (Choi et al., 2016; Portofino et al., 2013; Galvagno et al., 2009; Xiao et al., 2008; Wang et al., 2016; Janajreh and Raza, 2014a), but with little information about the applicability of this route for electricity and heat production.

On this background, the main objective of this work is to perform a theoretical assessment of the technical viability of TDF 


\section{Nomenclature}

$\dot{m}_{x} \quad$ mass flux of element $\mathrm{x}[\mathrm{kg} / \mathrm{s}]$

$h_{f g} \quad$ water vaporization enthalpy [MJ $\left./ \mathrm{kg}\right]$

$\Delta h_{x} \quad$ enthalpy change of the element $\mathrm{x}[\mathrm{MJ} / \mathrm{kg}]$

$Q_{G} \quad$ heat lost in the reactor [MW]

$\eta_{\text {gasifier }}$ reactor cold gas efficiency [\%]

$\mathrm{HHW}_{\mathrm{x}}$ higher heating value of element $\mathrm{x}\left[\mathrm{MJ} / \mathrm{kg}_{\text {fuel }}\right]$
$\mathrm{LHW}_{\mathrm{x}} \quad$ lower heating value of element $\mathrm{x}\left[\mathrm{MJ} / \mathrm{kg}_{\text {fuel }}\right]$

TDF Tire Derived Fuel

ICE-G internal combustion engine driving an electric generator

GT-G gas turbine driving an electric generator

BFBG Bubbling Fluidized Bed Gasifier gasification for electric and thermal power generation, from the producer gas combustion in an internal combustion engine driving an electric generator (ICE-G) and in a gas turbine driving an electric generator (GT-G). This study provides a support for decision makers in order to select the correct technology for the desired applications from the energetic valorization of this waste.

\section{Methodology for the technical analysis}

The study evaluated the implementation of waste tires gasification for electricity generation using two different technology. In both cases, are performed the mass and energy balance in all components of the configuration. The generation efficiencies of electricity, heat and the overall efficiency were also determined. In the final stage, a comparison taking into account the thermody- namic efficiency of different cases was performed. Fig. 1 shows the technical analysis methodology for gasification of TDF for electric and thermal energy generation.

\section{Waste tire gasification}

The tire life cycle consists generally of five main stages, comprising the extraction of raw materials, production, consumption (use), waste tire collection and processing for recycling or disposal, depending on the local conditions of each country or region where they are produced or sold (Van Beukering and Janssen, 2001).

Tires have a mixed composition of carbon black, elastomer compounds, and steel cord, in addition to several other organic and inorganic components. Fig. 2 (ETRMA, 2014) shows a view of the tires average composition.

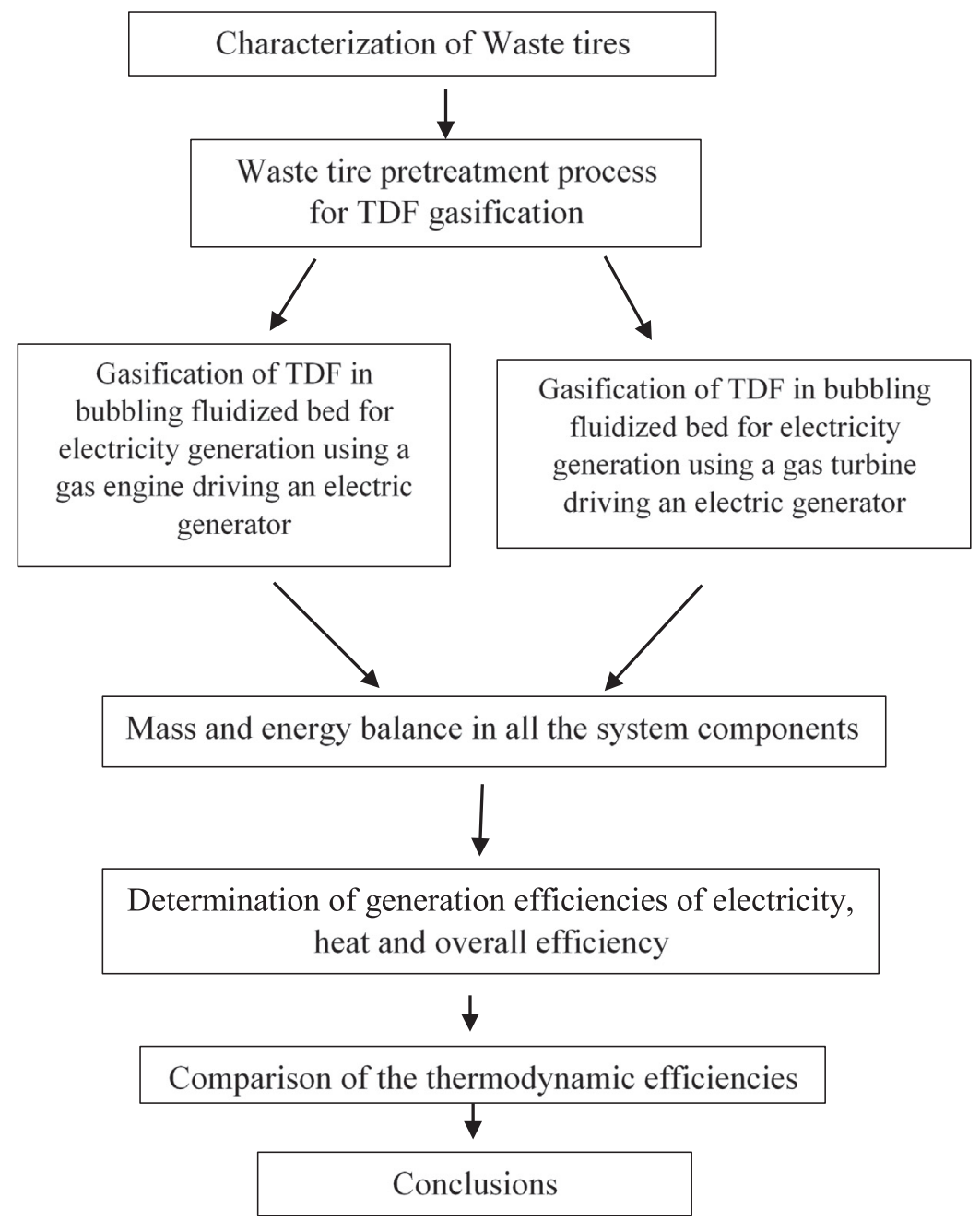

Fig. 1. Technical methodology for gasification of TDF for electric and thermal energy generation. 


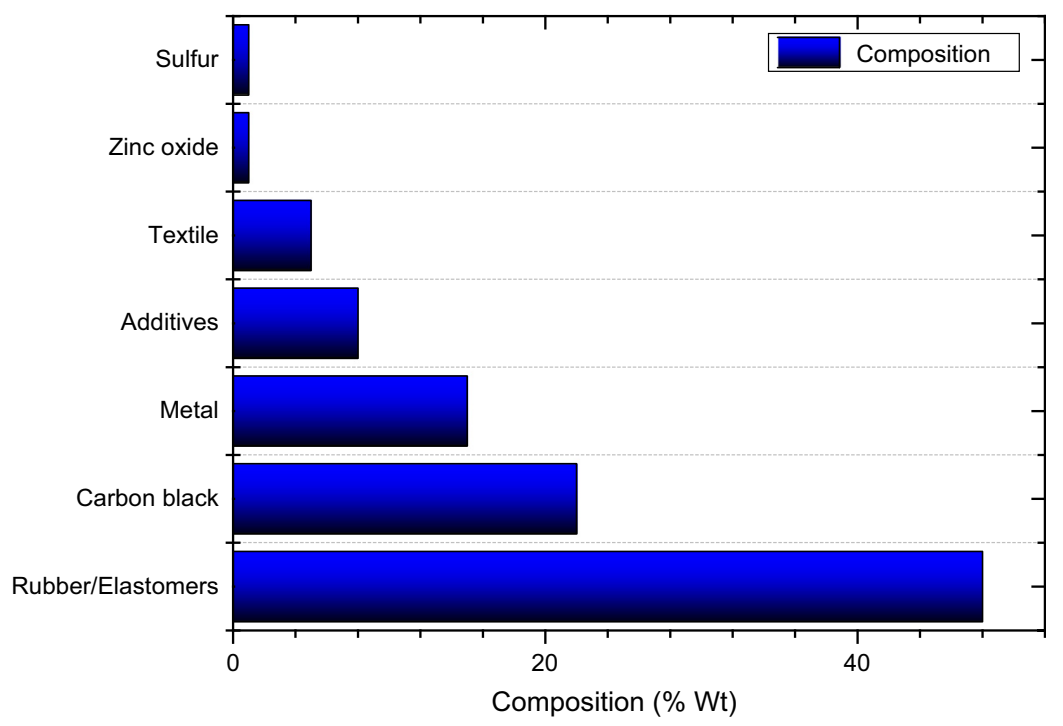

Fig. 2. Average composition of a tire.

The main components of the tires, the rubbery materials, are presented in the form of $\mathrm{C}_{\mathrm{x}} \mathrm{H}_{\mathrm{y}}$, with some fibrous materials, and they are considered thermoset polymers (Leung and Wang, 1998). Vehicle tires (both passenger and truck) are mainly a blend of natural (NR) and synthetic rubber (SR), such as butyl rubber (BR) and styrene-butadiene copolymer (SBR) (Martinez et al., 2013). The NR comes from Hevea tree, while the SR is generally derived from petroleum-based products (Shulman, 2004). NR has unique elastic properties and it is an essential element of a tire.

Analyzing different rubber compounds, several authors report different results of proximate and elemental analysis, as shown in Table 1 (Lee et al., 1995; Zhang et al., 2008; Chang, 1996; González et al., 2001; Williams and Richard, 1995; Orr et al., 1996; Cunliffe and Williams, 1998; Lanoir et al., 1998) and Table 2 (Rodríguez et al., 2001; Zhang et al., 2008; Isabel de Marco Rodriguez et al., 2001; Chang, 1996; González et al., 2001; Laresgoiti et al., 2004; Cunliffe and Williams, 1998; Arion et al., 2001; Williams and Richard, 1995; Orr et al., 1996; Lanoir et al., 1998) respectively. For obtaining the average content of elements in tires, each part of tire must be analyzed.

The higher heating value was estimated using the mean elemental compositions reported in Table 2 and the Modified Dulong Eq. (1), generally best for fuel-like, high carbon/hydrogen materials such as Tire Derived Fuels (TDF), on a moisture and ash-free basis (Buckley and Domalski, 1988), where $\mathrm{C}, \mathrm{H}_{2}, \mathrm{~S}, \mathrm{O}_{2}$, and $\mathrm{N}_{2}$ stand for the corresponding element mass percentage in the fuel.

Table 1

Proximate analysis for waste tire rubber by several authors.

\begin{tabular}{lllll}
\hline Reference & $\begin{array}{l}\text { Volatile } \\
\text { (wt\%) }\end{array}$ & $\begin{array}{l}\text { Fixed } \\
\text { carbon } \\
\text { (wt\%) }\end{array}$ & $\begin{array}{l}\text { Moisture } \\
\text { (wt\%) }\end{array}$ & $\begin{array}{l}\text { Ash } \\
\text { (wt } \\
\%)\end{array}$ \\
\hline 16 & 67.3 & 28.5 & 0.5 & 3.7 \\
17 & 61.61 & 22.66 & 1.72 & 14.01 \\
18 & 62.32 & 26.26 & 1.31 & 10.29 \\
19 & 61.9 & 29.2 & 0.7 & 8.0 \\
20 & 66.5 & 30.3 & 0.8 & 2.4 \\
21 & 68.7 & 23.3 & 0.4 & 7.6 \\
22 & 62.2 & 29.4 & 7.1 & 1.3 \\
23 & 64.0 & 30.7 & 0.9 & 4.4 \\
\hline
\end{tabular}

$$
\begin{aligned}
H H V= & {\left[78.31 \mathrm{C}+359.32\left(\mathrm{H}_{2}-\frac{O}{8}\right)+22.12 \mathrm{~S}\right.} \\
& \left.+11.87 \mathrm{O}_{2}+5.78 \mathrm{~N}_{2}\right] 0.0041868(\mathrm{MJ} / \mathrm{kg})
\end{aligned}
$$

The HHV is mathematically related with lower heating values (IPCC Guidelines, 2006) (LHV), by the Eq. (2) in MJ/kg.

$L H V=H H V-0.212 * H_{2}-0.0245 * M-0.008 * O_{2}(\mathrm{MJ} / \mathrm{kg})$

where $M$ is the percent moisture in the feedstock.

The TDF fuel is compact, has a consistent composition and low moisture content which are, all benefits to the fuel user in advanced thermal-conversion processes with low contaminant emissions.

\subsection{Waste tire processing}

While some combustion systems, like cement kilns, can accept whole tires, most of the thermal-conversion systems required that the tires be processed to certain sizes and purity to ensure that the material consistently meets the needs of the particular fuel users. Shredding waste tires to produce TDF uses standard material processing technologies which include shredding, component separation and dirt and other contaminants removal.

Processing waste tires into TDF mainly involves two physical processing stages: chipping/shredding and metal removal. In the

Table 2

Elemental analysis of waste tire rubber by several authors.

\begin{tabular}{lllllll}
\hline Reference & $\mathrm{C}(\mathrm{wt} \%)$ & $\mathrm{H}(\mathrm{wt} \%)$ & $\mathrm{N}(\mathrm{wt} \%)$ & $\mathrm{S}(\mathrm{wt} \%)$ & $\mathrm{O}(\mathrm{wt} \%)$ & Ash (wt\%) \\
\hline 24 & 74.2 & 5.8 & 0.3 & 1.5 & 4.7 & 13.5 \\
$17^{\mathrm{a}}$ & 81.24 & 7.36 & 0.49 & 1.99 & 8.92 & - \\
25 & 74.2 & 5.8 & 0.3 & 1.5 & 4.7 & 13.5 \\
18 & 74.4 & 6.94 & 0.21 & 1.6 & 5.02 & 10.21 \\
19 & 86.7 & 8.1 & 0.4 & 1.4 & 1.3 & 2.1 \\
26 & 81.16 & 7.22 & 0.47 & 1.64 & 2.07 & 7.44 \\
22 & 74.2 & 5.8 & 0.3 & 1.5 & 4.7 & 13.5 \\
16 & 83.8 & 7.6 & 0.4 & 1.4 & 3.1 & 3.7 \\
27 & 73.8 & 5.3 & 0.44 & 1.71 & 0.11 & 17.8 \\
20 & 85.8 & 8.0 & 0.4 & 1.0 & 2.3 & 2.4 \\
21 & 81.3 & 7.3 & 0.3 & 1.5 & - & 1.4 \\
$23^{\mathrm{a}}$ & 82.63 & 7.5 & 0.36 & 1.69 & - & - \\
28 & 86.7 & 6.9 & 0.3 & 1.9 & 0.9 & 3.3 \\
\hline
\end{tabular}

a Based on free of ash. 
first step, whole waste tires are either fed into the shredder or have the beads removed prior to shredding. The processing equipment are typically high-shear, low-torque shredders. Scrap passenger and truck tires up to $1.22 \mathrm{~m}$ in outside diameter can be initially reduced in these rotary shear shredders to pieces ranging in size from 2.5 to $10 \mathrm{~cm}$, depending on the end-use. To produce TDF, whole tires are reduced to nominal $5 \mathrm{~cm}$ pieces using one shredder or a series of shredders, screening equipment, and magnetic separation equipment (ASTM, 2006). Magnetic separators are required to remove the steel. A screen in the discharge of the shredder controls the shred/chip size where the two-inch sized material falls through the screen openings, while the oversized material is recirculated back to the shredder. Because a significant amount of rubber is entrained and lost in the wire removal stream, downstream shredding and wire removal can be employed to recover additional rubber, make a cleaner steel product for sale as scrap and to avoid landfilling of this wire/rubber material. If smallersized TDF is specified, then more size reduction, metal and fiber separation, classifying, screening and cleaning equipment may be required.

In this study, it is considered that waste tires will be processed using an Eldan Tire Recycling Plant model E1500T. This plant needs $200 \mathrm{~kW}$ h of electricity to process $1-1.5 \mathrm{t}$ of waste tires per hour to produce TDF with size range of $0-4 \mathrm{~mm}$ (Evans). The main objective of scrap tire pretreatment is the steel separation from this waste and the reduction of the fuel particle size before its introduction in the gasification island. The final dimensions of the fuel particles will depend on the gasifier technology.

\subsection{TDF gasification}

Gasification is a promising technology for waste based power generation (Mendiburu et al., 2014; Mota et al., 2015; Couto et al., 2015). Is a high-temperature process (873-1273 K), that decomposes the waste into gaseous fuel, primarily hydrogen, carbon monoxide, and carbon dioxide. Some tars (PAH- polycyclic aromatic hydrocarbon), char, methane, water, and other constituents also are formed (Reed and Das, 1998; Ismail et al., 2016; van de Beld et al., 2001; Pedroso et al., 2013). Hydrogen and carbon monoxide are the desired product gases, because a mixture of them can be fed directly to ICE-G and GT-G for power generation or can be used for chemicals synthesis. The main gasification reactions of carbonaceous fuels are as follows (Reed and Das, 1998):

$$
\begin{aligned}
& \mathrm{C}+\mathrm{H}_{2} \mathrm{O} \leftrightarrow \mathrm{CO}+\mathrm{H}_{2} \quad \Delta \mathrm{H}_{298}^{0}=131.5 \mathrm{~kJ} \cdot \mathrm{mol}^{-1} \\
& \mathrm{C}+\mathrm{CO}_{2} \leftrightarrow 2 \mathrm{CO} \quad \Delta \mathrm{H}_{298}^{0}=172 \mathrm{~kJ} \cdot \mathrm{mol}^{-1} \\
& \mathrm{C}+2 \mathrm{H}_{2} \leftrightarrow \mathrm{CH}_{4} \quad \Delta \mathrm{H}_{298}^{0}=-74 \mathrm{~kJ} \cdot \mathrm{mol}^{-1} \\
& \mathrm{CO}+\mathrm{H}_{2} \mathrm{O} \leftrightarrow \mathrm{CO}_{2}+\mathrm{H}_{2} \quad \Delta \mathrm{H}_{298}^{0}=-41 \mathrm{~kJ} \cdot \mathrm{mol}^{-1} \\
& \mathrm{CH}_{4}+\mathrm{H}_{2} \mathrm{O} \leftrightarrow \mathrm{CO}+3 \mathrm{H}_{2} \quad \Delta \mathrm{H}_{298}^{0}=-206 \mathrm{~kJ} \cdot \mathrm{mol}^{-1}
\end{aligned}
$$

The extent of the above reactions, the products distribution and the producer gas composition are function of gasification conditions, such as gasification agent, gasification temperature, stoichiometric ratio, residences time and fuel composition.

The waste tire gasification for energy generation is a technology that has been mainly carried out with plasma gasifiers due to the complex composition of this feedstock. The waste tire processing for obtaining TDF makes possible the employment of less complex gasification technologies.

The viability of the implementation of Bubbling Fluidized Bed Gasification (BFBG) of TDF, for electricity generation using a gas engine and a gas turbine, will be analyzed.
In BFBG the fuel feeding is typically at the base of the reactor bed. The bed material is fluidized by the gasifying agent (oxygen in our case) entering the gasifier through nozzles distributed along the bottom of the reactor. The fluidization velocity of the gasifying agent is low because there is no significant movement of the solid; the typical superficial velocity ranges $0.8-1.4 \mathrm{~m} / \mathrm{s}$. These gasifiers are usually used in plant sizes lower than $10 \mathrm{MW}$ (thermal). The reason for this size limitation is the requirement for good fuel distribution over the bed, which becomes more difficult with increasing diameter of the reactor.

The main advantages of fluidized beds include: better control of the reaction rates and temperatures, high specific capacity, easy adaptation to changes in fuel characteristics and lower efficiency losses caused by unreactive particles. These types of reactors also have low sensitivity to variations in fuel moisture (Zainal, 2010).

The energy balance in a gasifier employing air, oxygen, steam or mixtures as gasification agent is defined by Eq. (Prins et al., 2003; Karamarkovic and Karamarkovic, 2010) (6):

$$
\begin{array}{rl}
\dot{m}_{\mathrm{TDF}} & L H V_{\mathrm{TDF}}+\dot{m}_{\text {air }} \Delta h_{\text {air }}+\dot{m}_{\mathrm{O}_{2}} \Delta h_{\mathrm{O}_{2}}+\dot{m}_{\mathrm{H}_{2} \mathrm{O}}\left(h_{f g}+\Delta h_{\mathrm{H}_{2} \mathrm{O}}\right) \\
= & \dot{m}_{\text {PGas }}\left(\Delta h_{\text {PGas }}+L H V_{\text {PGas }}\right)+\dot{m}_{\text {Char }}\left(\Delta h_{\text {char }}+L H V_{\text {char }}\right) \\
& +\dot{m}_{\text {ashes }} \Delta h_{\text {ashes }}+Q_{G}
\end{array}
$$

where: $\dot{m}_{x}$ is the mass flux of the element $\mathrm{x}, h_{f g}$ is the water vaporization enthalpy, $\Delta h_{x}$ is the enthalpy change of the element $x, Q_{G}$ is the heat lost in the reactor, Pgas (producer gas) and $L H V$ is the lower heating values in $\mathrm{MJ} / \mathrm{kg}$.

Fig. 3 shown the main mass and energy fluxes considered in the BFBG for the balance in the studied case.

It was considered in the study that gasification agent was oxygen at standard conditions, and gasification occurs at Carbon Boundary Point, i.e. when it is incorporated into the exact amount the gasification agent, ensuring complete gasification of the fuel with no char formation; the energy balance in the analyzed system (Fig. 3) is defined as follows:

$$
\begin{aligned}
\dot{m}_{\mathrm{TDF}} \cdot L H V_{\mathrm{TDF}}+\dot{m}_{\mathrm{O}_{2}} \Delta h_{\mathrm{O}_{2}}= & \dot{m}_{\mathrm{PGas}}\left(\Delta h_{\mathrm{PGas}}+L H V_{P G a s}\right)+\dot{m}_{\text {tar }} \Delta h_{\text {tar }} \\
& +\dot{m}_{\text {ashes }} \Delta h_{\text {ashes }}+Q_{G}
\end{aligned}
$$

Since gasification process intends to produce a clean fuel gas usable at ambient temperature, and considering that the gasification agent (oxygen in our case) is not pre-heated before entering the reactor; the cold gas efficiency $\left(\eta_{\text {gasifier }}\right)$ is defined as the ratio of the heat content of the producer gas generated by the gasification of the TDF to the heat released by TDF when it is totally burnt. The $\eta_{\text {gasifier }}$ is given by the Eq. (9):

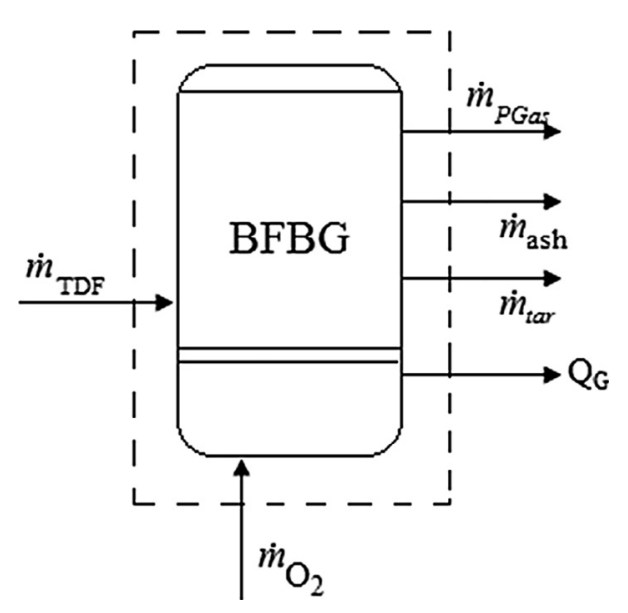

Fig. 3. Main mass and energy fluxes in the BFBG. 
$\eta_{\text {gasifier }}=\left(\frac{\dot{m}_{P G a s} \cdot L H V_{P G a s}}{\dot{m}_{T D F} \cdot L H V_{T D F}}\right)$

The $\eta_{\text {gasifier }}$ of the BFBG in our case was considered $67 \%$, considering the experimental results reported by several authors (Xiao et al., 2008; Karatas et al., 2013, 2012; Leung and Wang, 2003). The gasification process of TDF was modelled considering the theoretical results reported (Mitta et al., 2006) and (Janajreh and Raza, 2014 b). For the calculus was also considered a stoichiometric ratio oxygen/TDF of 2.64 according to the composition reported in Table 2 and a gasification temperature of $1223 \mathrm{~K}$.

\section{BFBG of TDF for electricity generation using a gas engine driving an electric generator}

The development of new engines and gas turbines able to use gas with low heating value as fuel (Barsali et al., 2015; Gobbato

Table 3

GE Jenbacher, model JMS 620 parameters.

\begin{tabular}{lll}
\hline Electrical output & $\mathrm{kW}_{\mathrm{el}}$ & 2433 \\
Recoverable thermal output $\left(180^{\circ} \mathrm{C}\right)$ & $\mathrm{kW}$ & 2743 \\
Energy input & $\mathrm{kW}_{\mathrm{th}}$ & 6205 \\
Fuel consumption based on a LHV of $18 \mathrm{MJ} / \mathrm{Nm}^{3}$ & $\mathrm{Nm}^{3} / \mathrm{h}$ & 1241 \\
Electrical efficiency & $\%$ & 39.2 \\
Thermal efficiency & $\%$ & 44.2 \\
Total efficiency & $\%$ & 83.4 \\
\hline
\end{tabular}

et al., 2015; Pérez et al., 2015) and the relatively high heating value of TDF enable the implementation of the gasification of TDF for electric and thermal power generation.

In this configuration, the combustion of the producer gas, derived from the gasification of TDF, in an ICE-G, is proposed. For the study, a Jenbacher gas engines generator, model JMS 620 (Table 3 Jenbacher Gas Engines) was considered.

In the proposed configuration (Fig. 4), after the waste tire pretreatment in the E1500T plant, the TDF is fed to the gasification island composed by a Bubbling Fluidized Bed Gasifier (Carbona ${ }^{\circledR}$ Technology) (E4TECH, 2009), an Air Separation Unit (ASU) and gas cleaning systems.

Using oxygen as gasification agent for gasification of TDF, considering the elemental composition as reported in Table 2 and the equivalent ratio of 0.3 , the gasification island yields $1.7 \mathrm{~kg}$ of producer gas per $\mathrm{kg}$ of TDF fed.

Fig. 5 shows the interconnection between the installations that compose the Gasification Island; which is formed by the ASU, the BFBG and the Cleaning System. The considered technology of BFBG was the RENUGAS, technology commercially available and tested (Pérez et al., 2015).

To determine the mass flow rate of TDF that will be introduced into the gasifier $\left(\dot{m}_{T D F}\right)$, the fuel fraction contained in the waste tires after steel separation is considered as well as its HHV and LHV are determined, by mean of the equation Eqs. (1) and (2) as discussed in Section 3. The obtained values were 36.80 and

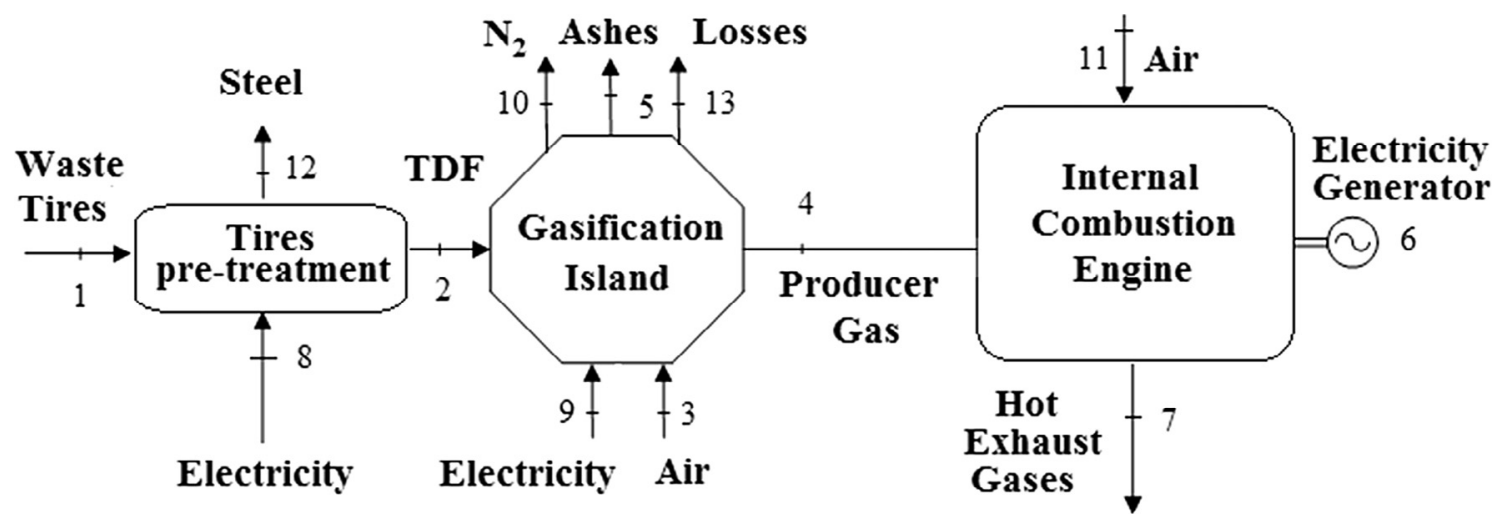

Fig. 4. Gasification of TDF for electricity generation using a gas engine driving an electric generator.

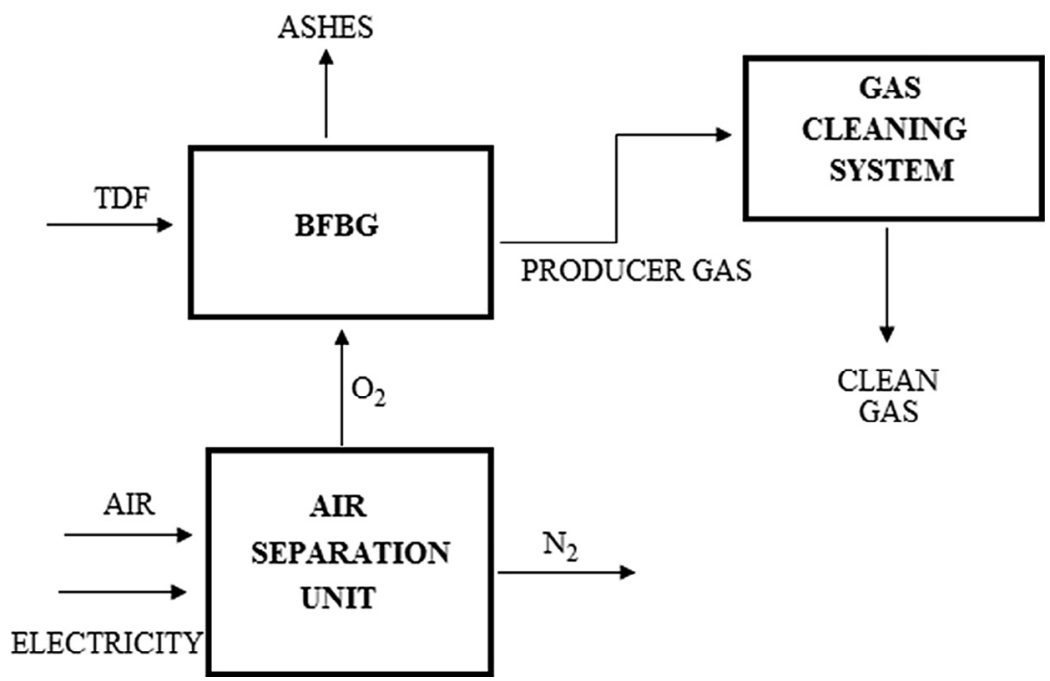

Fig. 5. Interconnection between the installations that compose the Gasification Island. 
$35.26 \mathrm{MJ} / \mathrm{kg}$ respectively, similar to the experimental values reported by other authors (Karatas et al., 2013, 2012; Leung and Wang, 2003; Mitta et al., 2006; Cooper et al., 1999; Clark et al., 1991).

Table 4 shows the results of the mass and energy balance for the implementation of this configuration for the TDF gasification for electricity generation using an ICE-G.

In this configuration, the net electricity generated is $1.49 \mathrm{MWe}$ with electric efficiencies of $21.41 \%$. The thermal power in the exhaust gases is 2.06 MWth. It was considered clean gas exit from the gasification island at standard ambient temperature and pressure (SATP) to feed the ICE-G. Hence, according to Eq. (9), the lost in the gasification island (Point 13) can be considered as:

Lost $=\dot{m}_{P G a s} \Delta h_{P G a s}+\dot{m}_{\text {ashes }} \Delta h_{\text {ashes }}+\dot{m}_{\text {tar }} \Delta h_{\text {tar }}+Q_{G}$

Approximately $75 \%$ of the lost in the gasification process correspond to the thermal energy transferred to the producer gas in the form of latent heat (Jankes et al., 2012; Basu, 2006; Higman and van der Burgt, 2008) $\left(\dot{m}_{\text {PGas }} \Delta h_{\text {PGas }}\right)$; that can be recovered for downstream applications. More complex is the recuperation of the tar chemical energy and the heats lost in the hot ashes and through the gasifier wall. In the case of the proposed plant the available latent heat in the producer gas at the gasifier exit, reaches 1.69 MWth., The thermal efficiency in the proposed configuration is $53.85 \%$.

Table 4

Results of the mass and energy balance for the implementation of the BFBG of TDF coupled to ICE-G model JMS 620 .

\begin{tabular}{lllll}
\hline Point & $\begin{array}{l}\text { Mass flow } \\
{\left[\mathrm{kg} \mathrm{s}^{-1}\right]}\end{array}$ & $\begin{array}{l}\text { Temperature } \\
{[\mathrm{K}]}\end{array}$ & $\begin{array}{l}\text { Pressure } \\
{[\mathrm{kPa}]}\end{array}$ & $\begin{array}{l}\text { Energy flow } \\
{[\mathrm{MW}]}\end{array}$ \\
\hline 1 & 0.292 & 298 & 101.3 & 6.86 \\
2 & 0.194 & 298 & 101.3 & 6.86 \\
3 & 0.978 & 298 & 101.3 & 0 \\
4 & 0.382 & 298 & 101.3 & 4.59 \\
5 & 0.018 & 298 & 101.3 & 0 \\
6 & - & - & - & 1.80 \\
7 & 4.27 & 740 & 101.3 & 2.03 \\
8 & - & - & - & 0.2 \\
9 & - & - & - & 0.18 \\
10 & 0.772 & 298 & 101.3 & 0 \\
11 & 3.89 & 298 & 101.3 & 0 \\
12 & 0.097 & 298 & 101.3 & 0 \\
13 & - & - & - & 2.26
\end{tabular}

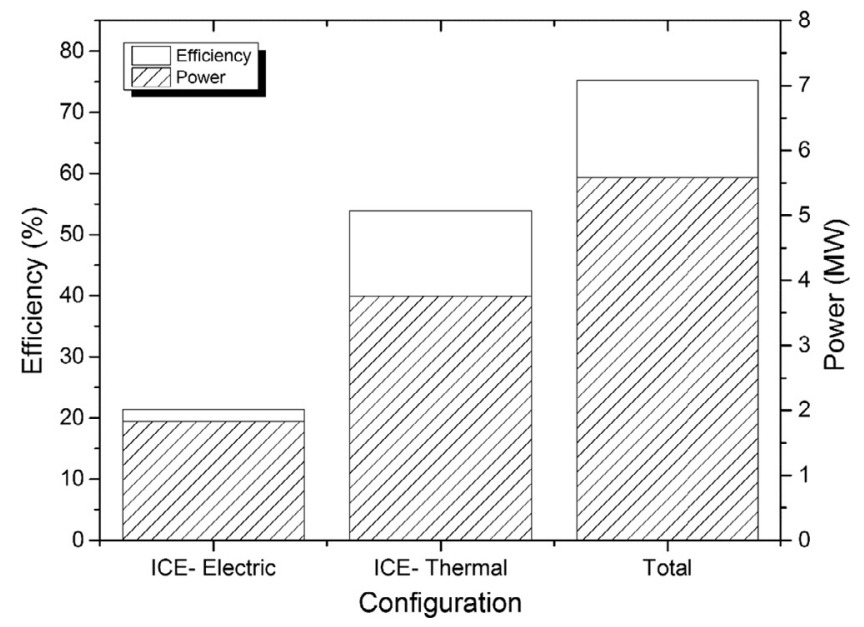

Fig. 6. Electric, thermal and total power and generation efficiencies in the ICE-G.

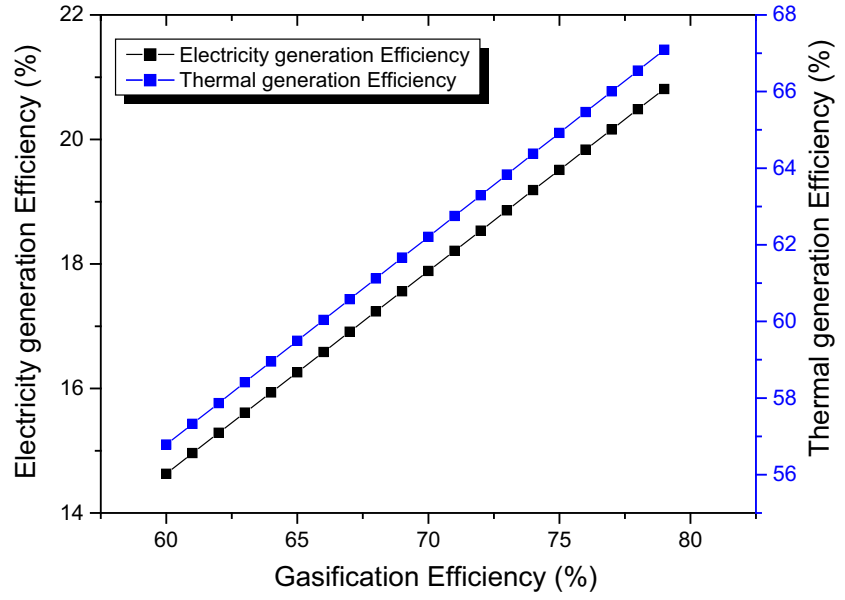

Fig. 7. Effects of gasification efficiency variation of on ICE-G thermal and electricity generation efficiency.

Fig. 6 shows the electric, thermal, total power generated and the generation efficiencies when the TDF derived producer gas is fed into the ICE-G for electricity and thermal power generation.

The thermal energy in the producer gas and engine exhaust gases could be also used for hot water production or refrigeration in absorption chiller (Gobbato et al., 2015; Edera and Kojima, 2002; Jankes et al., 2012). In this configuration the thermal energy represents the $67.2 \%$ of the total energy obtained in the TDF gasification. The global efficiency in this configuration could reach $75.25 \%$, and the capacity of processing scrap tires, will be function of the gasifier size or the number of gasifiers in the gasification island.

The gasifier efficiency is shows as a key parameter for the performance for this type of arrangement. Effects of gasification efficiency variation of on thermal and electricity generation efficiency was studied as shows in Fig. 7.

For the range of cold gas efficiencies analyzed, is possible observes the impacts in the electricity and thermal generation efficiencies of the variation in the gasification island performance, showing a low sensibility of the variation of this parameter in the energies generation performances of the studied configuration.

\section{BFBG of TDF for electricity generation using a gas turbine driving an electric generator}

In the second proposed alternative (Fig. 8), the producer gas will be generated with the same installations employed in the previous analyzed case. The producer gas will be used as feedstock for five Flex Turbine ${ }^{\circledR}$ model GT333S of $333 \mathrm{~kW}$ connected in parallel (considering the capacity of the gasifier and the gas turbine nominal capacity). The main characteristics of the Flex Turbine ${ }^{\circledR}$ model GT333S are shown in Table 5 (High Efficiency Gas Turbine Generator with Lowest Emissions, 2017).

Table 6 shows the results of the mass and energy balance for the implementation of this configuration for electricity generation using a GT-G.

In this case, the net electricity generated is $1.518 \mathrm{MWe}$, with an electric efficiency of $16.91 \%$. The thermal power in the exhaust gases is 2.53 MWth; the, thermal efficiency in this case is $60.58 \%$. Fig. 9 shows the electric, thermal and total power generated and generation efficiencies when the TDF derived producer gas is fed to the GT-G for electricity and thermal energy production.

In this case the thermal energy represents the $73.5 \%$ of the total energy obtained in the TDF gasification. The global energy generation efficiency with this configuration is $77.49 \%$. 


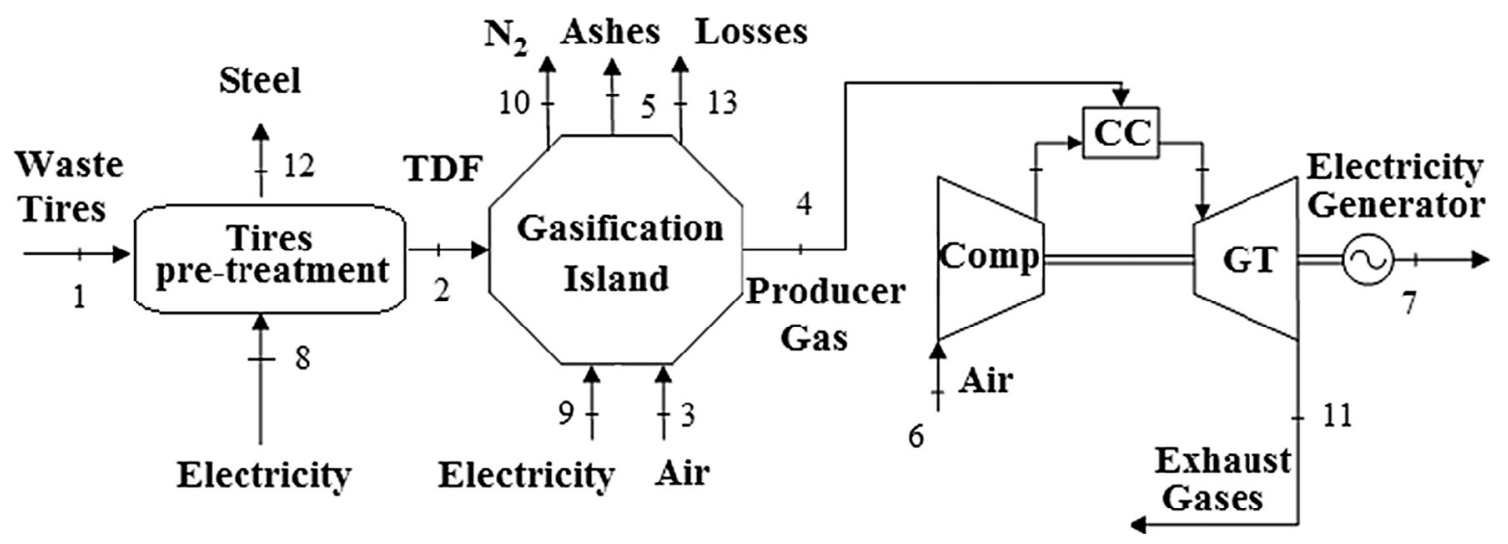

Fig. 8. Gasification of TDF for electricity generation using a gas turbine driving an electric generator.

Table 5

Flex Turbine ${ }^{\circledR}$ model GT333S parameters.

\begin{tabular}{lll}
\hline Electrical output & $\mathrm{kW}_{\mathrm{el}}$ & 333 \\
Recoverable thermal output $\left(264{ }^{\circ} \mathrm{C}\right)$ & $\mathrm{kW}$ & 556 \\
Energy input & $\mathrm{kW}_{\text {th }}$ & 1025 \\
LHV requirement WI & $\mathrm{MJ} / \mathrm{Nm}^{3}$ & $12.1-22.3$ \\
Producer gas temperature requirements & ${ }^{\circ} \mathrm{C}$ & -1 to 46 \\
Electrical efficiency without gas booster & $\%$ & 33 \\
Thermal efficiency & $\%$ & 55 \\
Total efficiency & $\%$ & 88.4
\end{tabular}

"Wobbe Index Lower heating value.

Table 6

Results of the mass and energy balance for the implementation of the BFBG of TDF coupled to six GT-G.

\begin{tabular}{lllll}
\hline Point & $\begin{array}{l}\text { Mass flow } \\
{\left[\mathrm{kg} \mathrm{s}^{-1}\right]}\end{array}$ & $\begin{array}{l}\text { Temperature } \\
{[\mathrm{K}]}\end{array}$ & $\begin{array}{l}\text { Pressure } \\
{[\mathrm{kPa}]}\end{array}$ & $\begin{array}{l}\text { Energy flow } \\
{[\mathrm{MW}]}\end{array}$ \\
\hline 1 & 0.292 & 298 & 101.3 & 6.86 \\
2 & 0.194 & 298 & 101.3 & 6.86 \\
3 & 0.978 & 298 & 101.3 & 0 \\
4 & 0.382 & 298 & 101.3 & 4.59 \\
5 & 0.018 & 298 & 101.3 & 0 \\
6 & 10.53 & 298 & 101.3 & 0 \\
7 & - & - & - & 1.52 \\
8 & - & - & - & 0.2 \\
9 & - & - & - & 0.14 \\
10 & 0.772 & 298 & 101.3 & 0 \\
11 & 10.86 & 537 & 101.3 & 2.53 \\
12 & 0.097 & 298 & 101.3 & 0 \\
13 & - & - & - & 2.262 \\
\hline
\end{tabular}

The effects of gasification efficiency variation of on thermal and electricity generation efficiency was also studied in this configuration as shows in Fig. 10.

Is possible note that the effect in the electricity and thermal generation efficiencies of the gasification island performance variation, in in this configuration is more significative than when ICE-G is implemented, but still with a relatively low impact.

\section{Comparative technical analysis of the studied cases}

Fig. 11 shows a comparison of results obtained for the electric, thermal and total power generation from the TDF gasification in the studied configurations.

There is a slight difference between the overall generation efficiencies for both configurations. The total power generation in the GT-G is slightly higher (3\%) than the total power generated in the ICE-G. Nevertheless the differences in the electric and thermal

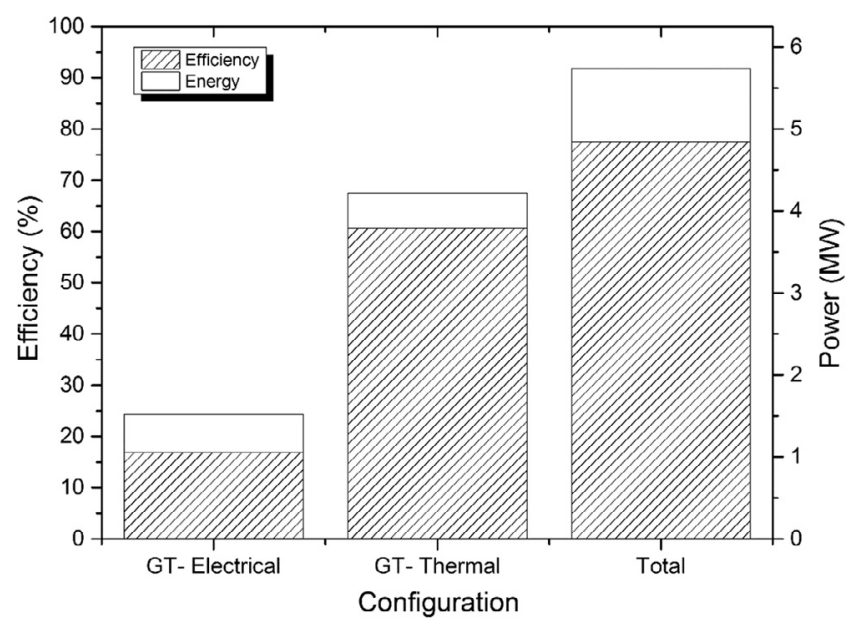

Fig. 9. Electric, thermal and total power and generation efficiencies in the GT-G.

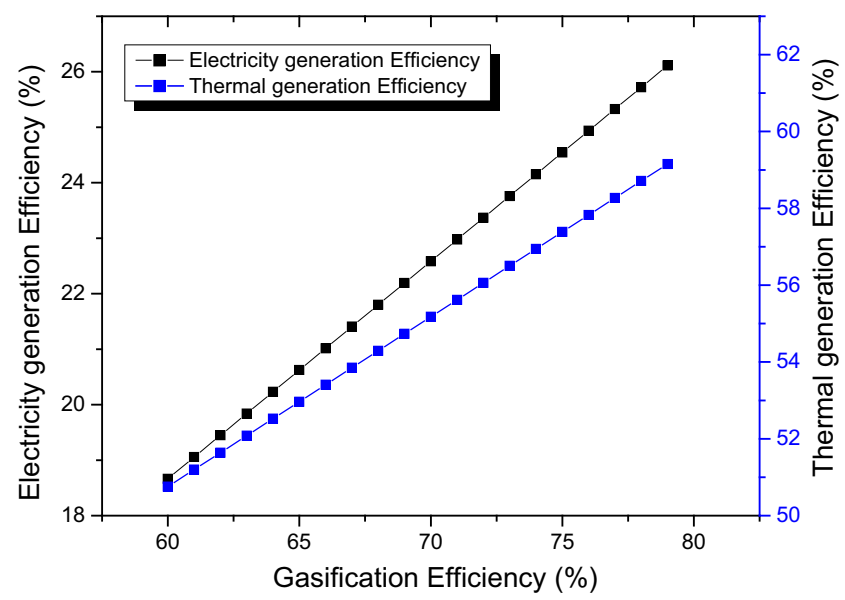

Fig. 10. Effects of gasification efficiency variation of on thermal and electricity generation efficiency.

power generation efficiencies between both configurations are more pronounced, being the electric efficiency $20.4 \%$ higher in the ICE-G than in the GT-G, and the thermal generation efficiency $12.5 \%$ lower in the ICE-G than in the GT-G, favoring the selection of the technology according to the intended main application (electricity or thermal application). 


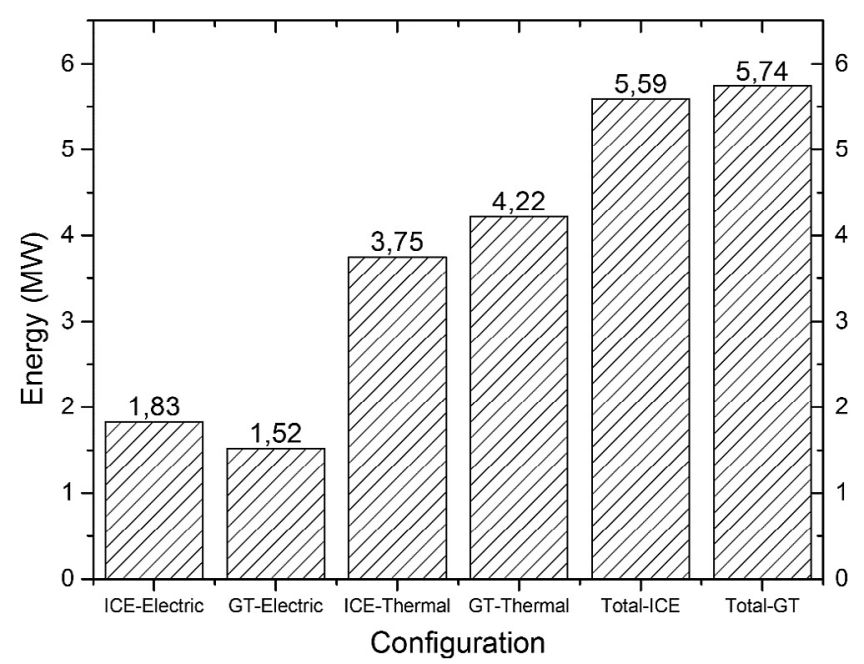

Fig. 11. Electric, thermal and total power generated by combustion of producer gas derived of gasification of TDF in the ICE-G and GT-G.

With the use of the producer gas of TDF to feed an ICE-G, it is possible to produce up to $7.67 \mathrm{MJ}$ and $10.62 \mathrm{MJ}$ of electric and thermal energy, respectively, per kilogram of TDF gasified. In the case that the producer gas is used to feed a GT-G is possible to produce up to $6.06 \mathrm{MJ}$ and $13.03 \mathrm{MJ}$ of electric and thermal energy respectively per kilogram of gasified TDF when a BFBG and oxygen as oxidant is used in the gasification process.

\section{Conclusions}

An assessment of the technical viability of TDF gasification for electric and thermal power generation, including the producer gas combustion in an internal combustion engine driving an electric generator and the use of the producer gas in a gas turbine, was performed. Despite the efficiency lost in the considered gasification technology, the TDF gasification showed to be a promising route for energetic valorization of waste tires, considering the complexity of this residue. In the routes for electric and thermal energy production evaluated, it was not found a significant difference in the total power generation efficiencies in both configurations. The combustion of producer gas derived from the gasification of TDF, in an ICE-G, appears to be a more efficient route for electricity generation (21.4\%) when compared with the efficiency obtained with the use of GT-G (16.91\%), in opposition with the results obtained for the efficiencies of thermal energy generation. In the GT-G the thermal efficiency reaches $60.58 \%$ while in the ICE-G, this parameter reaches $53.85 \%$. The energy parcel of thermal energy in both studied case was essential for the elevated global efficiency in both cases, representing 67.2 and $73.5 \%$ of the total energy available when TDF producer gas is used in ICE-G or in GT-G respectively. When implemented the TDF gasification for energy production with ICE-G it is possible produce up to $7.67 \mathrm{MJ}$ and $10.62 \mathrm{MJ}$ of electric and thermal energy, respectively per kilogram of gasified TDF. The implementation of GT-G favors the thermal energy instead electric energy; producing up to $13.03 \mathrm{MJ}$ of thermal energy and 6.06 MJ of electric energy per kilogram of gasified TDF

\section{Acknowledgments}

The authors are grateful to the National Council for Scientific and Technological Development (CNPq) (processes 166219/20150 and $165937 / 2015-7$ ) for financing support to this research.

\section{References}

ABRELPE, 2015. Overview of Solid Waste in Brazil. Available at: http://www. abrelpe.org.br. Access in: June 23 (in Portuguese).

Andrade, H.S., 2007. Scrap Tires: Possible Reuse Alternatives. Course Conclusion Work (Graduation in Economics). Federal University of Santa Catarina, Brazil (in Portuguese).

Arion, A., Baronnet, F., Lartiges, S., Birat, J.P., 2001. Characterization of emissions during the heating of tyre contaminated scrap. Chemosphere, 42, 5(7), 853-859.

ASTM, 2006. The American Society for Testing and Materials. Standard Practice for Use of Scrap Tire-Derived Fuel. ASTM D6700-01.

Barsali, S., De Marco, A., Giglioli, R., Ludovici, G., Possenti, A., 2015. Dynamic modelling of biomass power plant using micro gas turbine. Renewable Energy 80, 806-818.

Basu, P., 2006. Combustion and Gasification in Fluidized Beds. Taylor \& Francis, p. 496.

Buckley, T.J., Domalski, E.S., 1988. (Discussion by Rigo, H. G.), Evaluation of data on higher heating values and elemental analyses for refuse-derived fuels. In: 13th Biennial ASME Solid Waste Processing Conf., Philadelphia, PA, pp. 16-24 of Discussions Supplement, May 1-4, 1988.

Chang, Yu-Min, 1996. On pyrolysis of waste tire: Degradation rate and product yields. Resour. Conserv. Recycl. 17 (2), 125-139.

Choi, Gyung-Goo, Oh, Seung-Jin, Kim, Joo-Sik, 2016. Non-catalytic pyrolysis of scrap tires using a newly developed two-stage pyrolyzer for the production of a pyrolysis oil with a low sulfur content. Appl. Energy 170 (15), 140-147.

Clark, G., Meardon, K., Russe, D., 1991. Burning Tires for Fuel and Tire Pyrolysis: Air Implications. US Environmental and Protection Agency. Report Number EPA450/3-91-07. December.

Cooper, C.D., Kim, B., MacDonald, J., 1999. Estimating the lower heating values of hazardous and solid wastes. J. Air Waste Manag. Assoc. 49 (4), 471-476.

Couto, N., Silva, V., Monteiro, E., Teixeira, S., Chacartegui, R., Bouziane, K., Brito, P.S. D., Rouboa, A., 2015. Numerical and experimental analysis of municipal solid wastes gasification process. Appl. Therm. Eng. 78, 185-195. 5 March.

Cunliffe, Adrian M., Williams, Paul T., 1998. Composition of oils derived from the batch pyrolysis of tyres. J. Anal. Appl. Pyrol. 44 (2), 131-152.

E4TECH, 2009. Review of technology for the gasification of biomass and wastes. Available from: URL: http://www.ecolateral.org/gasificationnnfc090609.pdf.

Edera, M., Kojima, H., 2002. Development of a new gas absorption chiller heateradvanced utilization of waste heat from gas-driven co-generation systems for air-conditioning. Energy Convers. Manage. 43, 1493-1501.

ETRMA, 2014. End of life tyres - A valuable resource with growing potential - 2014 edition. Available at: http://www.etrma.org/uploads/Modules/ Documentsmanager/20150408-statistics-booklet-2014-final-\%28modified\% 29.pdf.

Evans, R. Waste Tire Processing Technology Comparison \& Contact Database. Project code: TYR0009-06. The Waste \& Resources Action Programme.

Galvagno, S., Casciaro, G., Casu, S., Martino, M., Mingazzini, C., Russo, A., Portofino, S., 2009. Steam gasification of tyre waste, poplar, and refuse-derived fuel: A comparative analysis. Waste Manage. 29 (2), 678-689.

Gobbato, P., Masi, M., Benetti, M., 2015. Performance analysis of a producer gasfuelled heavy duty SI engine at full load operation. Energy Procedia 82, 149155.

González, Juan F., Encinar, José M., Canito, José L., Rodríguez, Juan J., 2001. Pyrolysis of automobile tyre waste. Influence of operating variables and kinetics study. J. Anal. Appl. Pyrolysis, 58-59, pp. 667-683 (1 April).

High Efficiency Gas Turbine Generator with Lowest Emissions, 2017. Flex Turbine ${ }^{\circledR}$ GT333S. http://www.flexenergy.com/project-view/flex-turbine-gt333s/. Accessed on April 27, 2017.

Higman, Christopher, van der Burgt, Maarten, 2008. Gasification. Gulf Professional Publishing, Burlington, p. 456.

IPCC Guidelines, 2006. Vol. II, Section 1.4.1.2, Box 1.1.

Isabel de Marco Rodriguez, Laresgoiti, M.F. Cabrero, M.A., Torres, A., Chomón, M.J., Caballero, B., 2001. Pyrolysis of scrap tyres. Fuel Process. Technol. 72 (1), 9-22.

Ismail, Hamza Y., Abbas, Ali, Azizi, Fouad, Zeaiter, Joseph, 2016. Pyrolysis of waste tires: A modeling and parameter estimation study using Aspen Plus ${ }^{\circledR}$. Waste Manage., Available online 27 October.

Janajreh, Isam, Raza, Syed Shabbar, 2014. Gasification of waste tires. In: 2nd International Conference on Sustainable Solid Waste Management, Athens, June 2014

Janajreh, Isam, Raza, Syed Shabbar, 2014. Gasification of waste tires. In: Athene 2014: 2nd International Conference on Sustainable Solid Waste Management.

Jankes, G., Trninic, M., Stamenic, M., Simonovic, T., Tanasic, N., Labus, J., 2012. Biomass gasification with CHP. Production: a review of the state-of-the-art technology and near future perspectives. Therm. Sci. 16, 115-130.

Jankes, G., Trninic, M., Stamenic, M., Simonovic, T., Tanasic, N., Labus, J., 2012. Biomass gasification with CHP production: A review of state of the art technology and near future perspectives. Therm. Sci. 16 (1), 115-130.

Jenbacher gas engines JMS 620 GS-B.L. Technical Specification. GE Jenbacher GmbH \& Co OHG A-6200 Jenbach, Austria.

Karamarkovic, R., Karamarkovic, V., 2010. Energy and exergy analysis of biomass gasification at different temperatures. Energy 35 (2), 537-549.

Karatas, Hakan, Olgun, Hayati, Akgun, Fehmi, 2012. Experimental results of gasification of waste tire with air\&CO2, air\&steam and steam in a bubbling fluidized bed gasifier. Fuel Process. Technol. 102, 166-174. 
Karatas, Hakan, Olgun, Hayati, Engin, Berrin, Akgun, Fehmi, 2013. Experimental results of gasification of waste tire with air in a bubbling fluidized bed gasifier. Fuel 105, 566-571.

Lanoir, D., Trouvé, G., Delfosse, L., 1998. Laboratory scale studies on gaseous emissions generated by the incineration of an artificial automotive shredder residue presenting a critical composition. Waste Manage. 17 (8), 475-482.

Laresgoiti, M.F., Caballero, B.M., de Marco, I., Torres, A., Cabrero, M.A., Chomón, M.J., 2004. Characterization of the liquid products obtained in tyre pyrolysis. J. Anal. Appl. Pyrol. 71 (2), 917-934.

Lee, Jong Min, Lee, Jung Soo, Kim, Jung Rae, Kim, Sang Done, 1995. Pyrolysis of waste tires with partial oxidation in a fluidized-bed reactor. Energy 20 (10), 969-976.

Leung, D.Y.C., Wang, C.L., 1998. Kinetic study of scrap tyre pyrolysis and combustion. J. Anal. Appl. Pyrol. 45, 153-169.

Leung, D.Y.C., Wang, C.L., 2003. Fluidized-bed gasification of waste tire powders. Fuel Process. Technol. 84 (1-3), 175-196.

Lew, G., 1990. Preliminary Test Data from the Modesto Energy Company Evaluation Test. California Air Resources Board, Review Draft, Sacramento.

Marchiori, H., 2007. Tire use feasibility study as fuel in power generation. Final report, pp. 58.

Martinez, J.D., Puy, N., Murillo, R., Garcia, T., Navarro, M.V., Mastral, A.M., 2013. Waste tyre pyrolysis - A review. Renew. Sustain. Energy Rev. 23, 179-213.

Mendiburu, A.Z., Roberts, J.J., Carvalho Jr., J.A., Silveira, J.L., 2014. Thermodynamic analysis and comparison of downdraft gasifiers integrated with gas turbine, spark and compression ignition engines for distributed power generation. Appl. Therm. Eng. 66 (1-2), 290-297.

Mitta, Narendar R., Sergio Ferrer-Nadal, Lazovic, Aleks andar M., Parales, José F., Velo, Enric, Puigjaner, Luis, 2006. Modelling and simulation of a tyre gasification plant for synthesis gas production. Comput. Aided Chem. Eng. 21, 1771-1776.

Mota, R., Krishnamoorthy, G., Dada, O., Benson, S.A., 2015. Hydrogen rich syngas production from oxy-steam gasification of a lignite coal - A design and optimization study. Appl. Therm. Eng. 90, 13-22. 5 November.

Orr, Edward C., Burghard, John A., Tuntawiroon, Wisanu, Anderson, Larry L., Eyring, Edward M., 1996. Coprocessing waste rubber tire material and coal. Fuel Process. Technol. 47 (3), 245-259.
Pedroso, D.T., Machin, E.B., Silveira, J.L., Nemoto, Y., 2013. Experimental study of bottom feed updraft gasifier. Renewable Energy 57, 311-316.

Pérez, N.P., Machin, E.B., Pedroso, D.T., Roberts, J.J., Antunes, J.S., Silveira, J.L., 2015. Biomass gasification for combined heat and power generation in the Cuban context: energetic and economic analysis. Appl. Therm. Eng. 90, 1-12.

Portofino, Sabrina, Donatelli, Antonio, Iovane, Pierpaolo, Innella, Carolina, Civita, Rocco, Martino, Maria, Matera, Domenico Antonio, Russo, Antonio, Cornacchia Giacinto, Galvagno, Sergio, 2013. Steam gasification of waste tyre: Influence of process temperature on yield and product composition. Waste Manage. 33 (3), 672-678.

Prins, M.J., Ptasinski, K.J., Janseen, F.J.J.G., 2003. Thermodynamics of gas-char reactions: first and second law analysis. Chem. Eng. Sci., 58(3), 6, 1003-1011.

Reed, T.B., Das, A., 1998. Handbook of Biomass Downdraft Gasifier Engine Systems. The Biomass Energy Foundation Press.

Rodríguez, I., Laresgoiti, M.F., Cabrero, M.A., Torres, A., Chomon, M.J., Caballero, B. 2001. Pyrolysis of scrap tires. Fuel Process. Technol. 72 (1), 9-22.

Shulman, V.L., 2004. Tyre recycling, RAPRA review reports, vol 15, number 7, UK.

Van Beukering, P.J.H., Janssen, M.A., 2001. Trade and recycling of used tires in Western and Eastern Europe. Resour., Conserv. Recycling 33 (4), 235-265.

van de Beld, L., 2001. Cleaning of hot producer gas in a catalytic, reverse flow reactor, Final Report For: Novem (EWAB Program, Report no. 9605) and European Commission (AIR Program, AIR-CT93-1436).

Wang, Wei-Cheng, Bai, Chi-Jeng, Lin, Chi-Tung, Prakash, Samay, 2016. Alternative fuel produced from thermal pyrolysis of waste tires and its use in a DI diesel engine. Appl. Therm. Eng. 93 (25), 330-338.

Williams, Paul T., Bottrill, Richard P., 1995. Sulfur-polycyclic aromatic hydrocarbons in tyre pyrolysis oil. Fuel 74 (5), 736-742.

Xiao, Gang, Ni, Ming-Jiang, Chi, Yong, Cen, Ke-Fa, 2008. Low-temperature gasification of waste tire in a fluidized bed. Energy Convers. Manage. 49 (8), 2078-2082.

Zainal, A., 2010. Gasification of lignocellulosic biomass in fluidized beds for renewable energy development. Renew. Sustain. Energy Rev. 114, 2852-2862.

Zhang, Xinghua, Wang, Tiejun, Ma, Longlong, Chang, Jie, 2008. Vacuum pyrolysis of waste tires with basic additives. Waste Manage. 28 (11), 2301-2310. 